\title{
Study on the Relationship Between University School of Professional Structure and Its Development of Pillar Industries in Jilin Province
}

\author{
Chu Bing \\ Jilin Teacher's Institute of Engineering and Technology, \\ Changchun, Jilin, China 130052 \\ Email: chubingice@163.com
}

\begin{abstract}
Personnel training, scientific research, social services and cultural heritage are the four core functions of universities。 In this paper, Jilin Province, an objective analysis of the relationship between undergraduate programs between local colleges and universities and its pillar industries, the analysis of local colleges and universities undergraduate professional setting single, specialty and other similar issues with professional colleges and universities should be set up to foster brand and characteristics, course construction as the core group to try to form a professional discipline, Ideas and Countermeasures innovation of Local Universities specialty, training local industrial development needed practical personnel。
\end{abstract}

Keywords-Local Universities ; Major ; Mainstay Industry; Suggest

\section{INTRODUCTION}

Personnel training, scientific research, social services and cultural heritage are the four core functions of universities . With the development of science and technology, universities serve society function more and more countries in the world and the government highly valued National Plan of Education that "universities should firmly establish the awareness initiative to serve the community, to carry out a full range of services 。"Economic globalization has brought the deep conversion of economic development, the contribution rate of science and technology for the development of increasingly high society to knowledge production, dissemination and application of the main activities of colleges and universities, but also from the "ivory tower"into economic and social development of the "engine." Scientific and technological progress , theoretical innovation and personnel training to lead and promote the development of local economy and society,

to promote regional economic and improving comprehensive national strength has become especially important connotation of higher local social service functions of universities.

\section{DEVELOPMENT Status OF Higher EduCATION ABROAD}

From a global perspective, in response to the profound changes in social production, knowledge production, the United States, Japan, Germany, Canada, Britain, Russia and other countries have worked out their own development needs for education, science and technology development strategy 。 The common characteristic of the school:

On the classification institutions to maintain an independent existence Characteristic University; On the disciplines, with particular characteristics and advantages of discipline and service-oriented; On personnel training, attention to theory and practice, government departments and various sectors of culture with a high level of application-oriented professional elite. ${ }^{[1]}$

According to relevant statistics, scientific and technological resources of Jilin Province China accounted for the first 13, but the contribution rate of science and technology in the country Jilin Provincial Universities currently has 31 . But universities with a corresponding degree of professional disciplines advantage of the local pillar industry is still relatively low, the contribution of local enterprise development rate is not high, there are still many unresolved good question.

\section{JILIN GENERAL UNDERGRADUATE SCHOOL OF PROFESSIONAL STRUCTURE AND ITS INDUSTRIAL STRUCTURE RELATIONSHIP}

Changes in the industrial structure is a proportional relationship between changes in the three industries in the industrial economy, the industrial structure of the center of gravity shifted gradually toward the secondary industry and tertiary industry development from the first industry [2]. Change of industrial structure and professional structure of universities' mutual restraint, mutual influence, and in the industrial structure of the inevitable requirement for universities increase or new professional or professional integration to meet the needs of industrial restructuring. 


\section{A. Jilin Industrial Structure}

Industrial structure is between the various sectors of the national economy as well as various industrial sectors constitute the internal [3]. With the rapid development of the global economy, the industrial structure will be changed, Jilin Province is also a corresponding change in the industrial structure, the development of modern industrial structure changes will inevitably lead to changes in the structure of demand for talent, and talent supply structure to some extent dependent on the set discipline structure [4]. In April 2011, according to the "CPC Jilin Provincial People's Government of Jilin Province to speed up a number of opinions on the economic development mode shift" (Kyrgyzstan Fa [2010] No.19, hereinafter referred to as "views") and Jilin Provincial Committee of the Ninth Plenary Session of eleven "Recommendations on National Economic and Social development Twelfth five-Year Plan" requirement, according to the "second five" Industrial development Plan of Jilin Province, formulated the "pillar industries in Jilin Province jumped plan (2011-2015) . "In accordance with the "opinions" in determining the automobile, petrochemical, agricultural products processing the three pillar industries and equipment manufacturing, electronic information, pharmaceuticals, metallurgy, building materials, textile and other industries, is determined on the basis of our province, "second five" Plan of Industrial Development industrial development direction and goals, in the existing industrial base, and further define the main tasks of the province's pillar industries jumped, to build nine 100 billion industry [5].

rom the industrial economy overall strength of the situation, as of 2014 , the province's GDP 1.380381 trillion yuan, calculated at comparable prices, an increase of $6.5 \%$ over the previous year. Among them, the first industry was 152.456 billion yuan, an increase of $4.6 \%$; the secondary industry was 728.726 billion yuan, an increase of $6.6 \%$; Tertiary industry 499.199 billion yuan, an increase of $6.9 \%$. By the resident population, the province's per capita GDP reached 50,162 yuan (according to the annual average exchange rate of $\$ 8,166$ ), an increase of 6.5 percent over the previous year。Scale structure of the three industries is 11.0: 52.8: 36.2 , the economic growth rate was $6.8 \%, 55.6 \%$ and $37.6 \%$ respectively 2014 , above-scale industrial added value of 649.293 billion yuan, an increase of 6.6 percent over the previous year。Among them, the light industry realized an added value of 199.718 billion yuan, an increase of $7.8 \%$; heavy industry realized an added value of 449.575 billion yuan, an increase of $6.0 \%$ 。 Eight important industry realized a total added value of 533.999 billion yuan, an increase of $6.7 \%$, accounting for $82.2 \%$ of the total above-scale industrial added value of above-scale industrial growth rate of the province's contribution important industry reached $83.7 \%$ [6][7].
TABLE I 2011 - THE Key INDUSTRIES OF INDUSTRIAL AdDED VALUE IN 2014 AND ITS GROWTH RATE

\begin{tabular}{|l|c|c|c|c|}
\hline \multirow{2}{*}{ industry } & \multicolumn{4}{|c|}{ annual growth rate(\%) } \\
\cline { 2 - 5 } & 2011 & 2012 & 2013 & 2014 \\
\hline automotive industry & 10.6 & 16 & 11.3 & 6.2 \\
\hline petrochemical industry & 12.8 & 9.7 & 8.8 & 4.5 \\
\hline food industry & 24.3 & 17.3 & 9.5 & 3.4 \\
\hline information industry & 33.7 & 4.9 & 13.1 & 6.4 \\
\hline pharmaceutical industry & 32.4 & 14.3 & 21.1 & 15.4 \\
\hline metallurgy production & 23.7 & 16 & 13.9 & 9.0 \\
\hline energy industry & 14.3 & 0.6 & 7.3 & 2.8 \\
\hline textile industry & 16.1 & 19.1 & 11.8 & 14.9 \\
\hline
\end{tabular}

Source: 2011 - 2014 Jilin Province National Economic and Social Development Statistics Bulletin

\section{B. Undergraduate Jilin University Professional Structural Settings Status}

1)BASIC Undergraduate School in Jilin Province

A total of 31 colleges in Jilin Province, where the Ministry of Education subordinate institutions 2, 23 provincial general undergraduate colleges, private colleges 6 , undergraduate students as 454,357 people. Subject categories in accordance with the main distinction between professional and generally, mechanical, optical, electronic, automotive, transportation and other main subjects 14 universities; colleges and universities a chemical; Agricultural Universities 2; building university 2; Medicine Universities 2; Art Universities 2; Teachers College 6; water, electricity Universities 2. In fact, the ability of the province provincial universities serve the local economic and social development is clearly insufficient. Specific performance docking with the local pillar industries are not, such as building materials, metallurgy, textile these areas, provincial universities disciplines almost no convergence ${ }^{[8][9]}$.

TABLE II STATISTICS ORDINARY UNDERGRADUATE UNIVERSITIES IN JILIN PROVINCE

\begin{tabular}{|c|l|l|l|}
\hline No. & School Name & Administrations & Location \\
\hline 1 & ilin University & TheMinistryofEducation & Changchun \\
\hline 2 & Yanbian University & jilin & Yanbian \\
\hline 3 & Changchun University of Science and Technology & ilin & Changchun \\
\hline 4 & Northeast Dianli UNiversity & jilin & ilin \\
\hline 5 & Changchun University of Technology & jilin & Changchun \\
\hline 6 & jilin Jianzhu University & jilin & Changchun \\
\hline 7 & iilin Institute of Chemical Technology & jilin & ilin \\
\hline 8 & iilin Agricultural University & jilin & Changchun \\
\hline 9 & Changchun University of Chinese Medicine & jilin & \\
\hline
\end{tabular}




\begin{tabular}{|l|l|l|l|}
\hline 10 & Northeast Normal University & TheMinistryofEducation & Changchun \\
\hline 11 & Beihua University & jilin & Jilin \\
\hline 12 & Tonghua Normal University & jilin & Tonghua \\
\hline 13 & ilin Normal University & jilin & Siping \\
\hline 14 & ilin Engineering Normal University & jilin & Changchun \\
\hline 15 & Changchun Normal University & jilin & Changchun \\
\hline 16 & Baicheng Normal University & jilin & Baicheng \\
\hline 17 & ilin University Of Finance\&Economics & jilin & Changchun \\
\hline 18 & ilin Sport University & jilin & Changchun \\
\hline 19 & ilin University of the Arts & jilin & Changchun \\
\hline 20 & ilin Huaqiao University of Foreign Languages & $\begin{array}{l}\text { Jilin Province Department } \\
\text { of Education }\end{array}$ & Changchun \\
\hline 21 & iliin Business and Technology College & jilin & Changchun \\
\hline 22 & Changchun Institute Of Technology & jilin & Changchun \\
\hline 23 & Agriculture Science And Technology College & jilin & jilin \\
\hline 24 & iliin Police College & & \\
\hline
\end{tabular}

\begin{tabular}{|l|l|l|l|}
\hline 25 & Changchun University & jilin & Changchun \\
\hline 26 & Changchun guanghua school & $\begin{array}{l}\text { Jilin Province Department } \\
\text { of Education }\end{array}$ & Changchun \\
\hline 27 & Chang chun institute of finance and economics & $\begin{array}{l}\text { Jilin Province Department } \\
\text { of Education }\end{array}$ & Changchun \\
\hline 28 & Changchun School of Architecture & $\begin{array}{l}\text { Jilin Province Department } \\
\text { of Education }\end{array}$ & Changchun \\
\hline 29 & Changchun institute of technology & jilin Province Department \\
of Education & Changchun \\
\hline 30 & ilin Institute animation & Jilin Province Department \\
of Education & Changchun \\
\hline 31 & inlin Medical college & jilin & ilin \\
\hline
\end{tabular}

2) Professional Type and Set the Case

Colleges and universities undergraduate course catalog Fourth Amendment was promulgated in 2012, the new directory disciplines from the original 11 to $\$ 12$, the new Art category; professional category increased from 73 to $\$ 92$; professional from the original 635 kinds of down immediately to 506 kinds, including 352 kinds of basic professional, ad hoc professional 154 kinds. Universities of Jilin Undergraduate set point as follows:

TABLE III REGULAR UNDERGRADUATE PROFESSIONAL POINT OF JILIN STATISTICS OF UNIVERSITIES

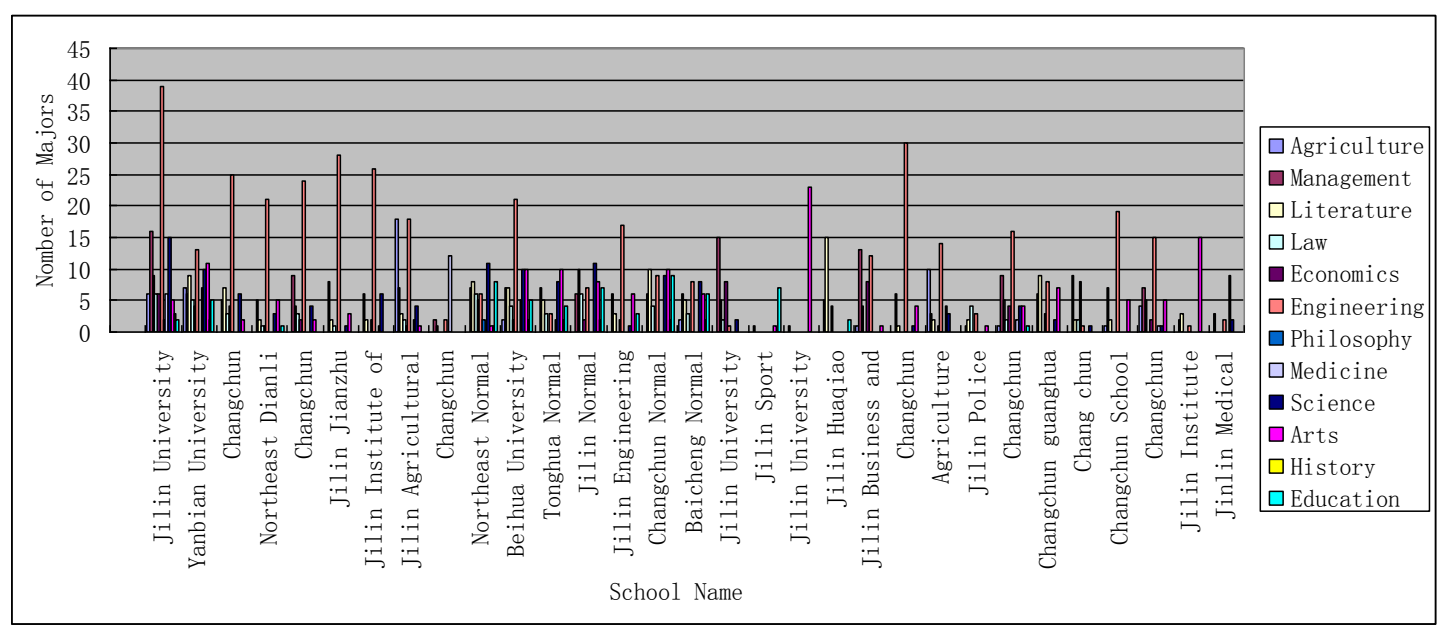

As of 2015, a total of Jilin Undergraduate Majors 1306, Gong Xuelei set point 389, accounting for $30 \%$ of the total; management class 197 , accounting for $15 \%$ of the total; the literary set point 147 , the total number of $11 \%$; pharmacological class set point 123 , accounting for $9 \%$ of the total; Art class set point 146, accounting for $11 \%$ of the total. Set professional point less philosophical class set four, accounting for $0.3 \%$ of the total; history class set point 16 , accounting for $1.2 \%$ of the total.

\section{JILIN UNIVERSITIES UNDERGRADUATE STRUCTURE}

It can be seen from problem analysis that although the structure of undergraduate colleges and universities in Jilin Province and trends adapt to the industrial structure, the degree of adaptation and internal is still insufficient.

a. Professional total growing too fast, the new professional with a certain blindness

b. Professional irrational, duplication of the same professional multi school rather serious. c. Pecialty, the advantages of professional, key professional is not obvious, and the overall strength is not high.

\section{UNDERGRADUATE COLLEGE JILIN PROFESSIONAL STRUCTURE OPTIMIZATION TIPS}

Professional colleges and universities should strengthen the government's macroeconomic adjustment management and control, in the disciplines set to be focused, closely around the local industrial structure adjustment, be professional structure and industrial structure homeostasis C Combined with in technological innovation, pay more attention to the regional economy and the contribution to economic and social development $[10]$.

\section{A. Combined with Industry Needs Professional} Structure Adjustment

According to the development trend of industrial structure adjustment and pillar industries and regional 
advantages, timely adjustment of professional structure, the creation of new professional, strengthen old professional. In particular, universities have industrial features professional to focus on the province's pillar industries demand talent shortage, increase optimization and construction-related professional. For stable foundation of traditional specialty, pay attention to the potential of interdisciplinary professional settings. For science, literature, education and other categories of professionals, to adopt appropriate policies to stabilize and make discipline structure, hierarchy, professional point of distribution is more reasonable. On the basis of stability, adjust and optimize the professional structure, reduce duplication of set point, so running level and further improve the quality of teaching.

\section{B. Establish a New System, Standardize Discipline \\ Structure Adjustment}

Government departments should establish a series of rules and regulations, Undergraduate College seriously consider professional structure set in Jilin problem, do the disciplines and professional planning, preparation of discipline construction guide that provides information services, and strengthen macro-control and management. Schools should also create some more specific work systems specifically for the professional aspects of development, the importance of discipline and restructuring the construction work from the policy clear. To adjust and optimize the structure of academic disciplines, improve the quality of personnel training, play an important guarantee.

\section{Adjust Professional Layout, Adding New Professional Scientific and Rational}

New professional to the actual needs of the community as the basis, we must carry out extensive and in-depth, targeted market research, talent demand and fully demonstrate the feasibility of forecasting. Relying on the revitalization of northeast old industrial base and revitalize key industries established in Jilin focus on the planning and design of the addition of new specialty, such as professional distribution, the graduate employment information and employment situation, shortage of professional talent market and other countries and regions. Conduct survey research to fully grasp the advantages and weaknesses, and improve education quality and school effectiveness. Follow the law of economic development, professional development and the combination of market discipline, and correctly handle the relationship between changes to adapt to the diversity of needs and to maintain a relatively stable professional. For new professional conduct regular checks continue to improve teaching quality and school level, multiple inspections not up to standard, the deadline for rectification or stop enrollment. Avoid the creation of new professional colleges and universities do not parrot, government departments should take macro-control mode the guidance of professional construction and positioning the university closely integrated schools promote the balanced and sustainable development disciplines.

\section{Emphasis on Discipline Construction, Widening}

\section{Professional Caliber}

Adjust not only the quantity but also the changes in the professional structure of professional content to adjust the personnel training mode reform, curriculum construction as the core, to try to form a professional disciplinary group to form wide caliber, thick foundation, strong ability to adapt to training mode. To carry out major construction provincial advanced exemplary disciplinary working, to the point, and all-round development; strengthen the teaching staff work, take the introduction and cultivation of combining a variety of training mode, continue to enhance faculty building work; strengthening higher education, teaching and research work mutual exchange between universities to promote mutual development. Try different joint inter-professional or related professional, organizedinterdisciplinary professional or adjust settings or restructuring departments between faculties according to the characteristics of disciplines and promote interdisciplinary, cross-disciplinary, professional development of emerging disciplines.

\section{REFERENCES}

[1] Zhangsen, France, the Russian American characteristic of the university of school-running characteristics and enlightenment [J]. Education Research Monthly, 2010.10:84-87

[2] Wangqing, Chongqing's industrial structure and college undergraduate study on the relationship between the structure [J]. Science and TechnologyManagement Research, 2008.7:198-200

[3] Jin Jiaping, Higher vocational colleges of zhejiang province professional Settings and adaptability research of industrial structure, Zhejiang university of technology master's thesis, 2011.12

[4] Chen Dongsong,Han Lizhu,. Modern industry based on the needs of jilin chemical structure optimization study of academic disciplines [J]. Journal of jilin institute of chemical industry, 2013.10:74-78

[5] Jilin province pillar advantage industry jumped plan (2011-2015)

[6] Jilin province national economy and social development statistical bulletin in 2014

[7] Wu Yusheng, Wang Bolu, Cai Jingyi, Gao Xuemei, Undergraduate course of common colleges and universities in Guangdong province present situation and adjust professional structure analysis $[\mathrm{J}]$. Modern Education Management, 2009.7:12-15

[8] Jinshu. Jilin province education system setting hearts meet force, crucial construction strong province of higher education $[\mathrm{N}]$. JiLin Daily, 2013.04.01

[9] Zhao Yanlin, Wangwen, Xu Jianping, Zhoujing. Local engineering colleges and universities of professional setting and serving local interaction research $[\mathrm{J}]$. Research in Higher Education , 2012.06:66-70

[10] Zhoujing, Qifang, Zhang Qiwu. Jilin province higher vocational colleges professional Settings present situation and the development countermeasures [J]. Vocational and Technical Education , 2013.26:9-13 